\title{
INFORMACINĖS INFRASTRUKTŪROS GALIMYBĖS VERTINTI APLINKOS IR VANDENS TARŠOS KOKYBE IGYVENDINANT DARNAUS VYSTYMOSI SPRENDIMUS
}

\author{
Ramute Naujikienè \\ Mykolo Romerio universitetas, Ateities g. 20, LT-08303, Vilnius, Lietuva, riman@mruni.eu \\ Dalè Dzemydienè \\ Mykolo Romerio universitetas, Ateities g. 20, LT-08303, Vilnius, Lietuva, daledz@mruni.eu \\ doi:10.13165/ST-14-4-1-15
}

\section{Santrauka}

Tikslas - išnagrinèti informacinès infrastruktūros galimybes teikti paslaugas vandens resursu apskaitos ir nuoteku valymo veikloje, pateikti duomenu saugyklu (DS) analizès būdus, kurie leistu ivertinti aplinkos ir vandens taršos rodiklius bei atlikti ju vertinimą atsižvelgiant $i$ darnaus vystymo reikalavimus.

Metodologija - mokslinès literatūros analizė atliekama siekiant atskleisti veiksnius, darančius įtakg darnaus vystymosi sprendimams. Pateiktos mokslininku aplinkos užterštumo situacijos vertinimo ǰžvalgos, tinkamų rodiklių paieška, kurie leidžia atskleisti aplinkos ir vandens užterštumo būklę nutekamuosiuose vandenyse. Antriniu duomenu analize atlikta siekiant atskleisti paviršinio vandens užterštumo vertinima Lietuvos apskrityse ir Baltijos jūros regione bei apibendrinti tyrimo rezultatai.

Rezultatai - pagal gautus nuoteku apskaitos ir taršos rodikliu analizès rezultatus, ekonominiu veiklos subjektu daroma tarša ir ịtaka Baltijos jūros regiono užterštumui nemažeja. Taršos rodiklių dinamika kinta, tačiau pastebimo tolygaus mažéjimo statistiniu duomenu analizè neatskleide. Svarbu kontroliuoti daromos taršos poveikị aplinkai, nuolat tikrinti valymo sistemu darba ir vykdyti ekologines pusiausvyros rodikliu apskaita. 
Tyrimo apribojimai - igyvendinant inovacinius sprendimus su ekonomikos pletra susijusiose srityse, veiksniai, darantys ịtaka darniam vystymui, ir ju rodikliu sistemos keisis. Analizuojant aplinkos kokybès sprendimus demesys komponentams - orui, vandeniui, klimato kaitai, kraštovaizdžiui ir biologinei įvairovei didès.

Praktiné reikšme - tyrimas atskleidžia darnaus vystymo reikalavimu vykdymo galimybes nuoteku apskaitos ir vandenvalos sektoriaus veikloje, identifikuoja egzistuojančias problemas, kurias reikia spręsti, norint užtikrinti vandens kokybę ir švaria aplinką.

Originalumas / vertingumas - straipsnyje analizuojamos problemos, susijusios su aplinkos užterštumo situacijos vertinimu, tinkamu rodikliu paieška, kurie leidžia atskleisti vandens užterštumo būklę nutekamuosiuose vandenyse Baltijos jūros regione. Pateikti tyrimo rezultatai vandens taršos kokybei vertinti igyvendinant darnaus vystymosi sprendimus.

Reikšminiai žodžiai: informaciness sistemos, duomenu saugyklos (DS), darni plètra, vandens taršos rodikliai.

Tyrimo pobüdis: koncepcinè analizè, duomenu tyrimo pristatymas.

\section{Ivadas}

Besivystančioms ir pažengusioms Europos Sąungos šalims tenka spręsti skirtingos svarbos darnaus vystymosi uždavinius, tačiau prioritetais išlieka nepamatuoto gamtos išteklių naudojimo ir švarios aplinkos išsaugojimo problemų sprendimo uždaviniai (den Boer et al., 2007). Jau 1992 m. pasaulio viršūnių susitikime Rio de Žaneire buvo suformuluotos darnaus vystymosi nuostatos - priimta darnaus vystymosi igyvendinimo veiksmų programa „Darbotvarkè 21 “ ir deklaracija, kurioje nurodyti pagrindiniai darnaus vystymosi principai (EC Sustainable..., 2014; Lietuvos Respublikos Vyriausybès 2009-09-16 nutarimas Nr. 1247 ir 2011-03-30 nutarimas Nr. 379). ES darnaus vystymosi strategija buvo patvirtinta $2001 \mathrm{~m}$. Geteborge (Švedija) vykusiame Europos Tarybos viršūnių pasitarime, kuriame buvo konstatuota, kad darnus vystymasis yra ilgalaike ES strategija, užtikrinanti švarią ir sveiką aplinką bei gerèjančią gyvenimo kokybę dabartinei ir ateinančioms kartoms.

Tačiau, pavyzdžiui, stebint dirvožemio taršos procesus ES asocijuotose šalyse narèse, galima vertinti apytikriai 250000 galinčių teršti veiklos šaltinių. Kaip rodo nacionalinės ES šalių ataskaitos, dažniausiai aptinkami dirvožemio teršalai yra sunkieji metalai ir mineralinès alyvos, o dažniausiai randami teršalai požeminiuose vandenyse taip pat yra mineralinès alyvos ir chlorinti angliavandeniliai. Nemaža dalis, apie 35 proc., išlaidų išvalymui skiriama iš viešojo sektoriaus biudžeto. Nors šioje srityje yra daug dirbama, tačiau prireiks dešimtmečių norint išvalyti jau padarytos taršos palikimą, o kai kurie taršos procesai intensyvejja, nors ES šalys moka nemažus aplinkos taršos mokesčius.

Igyvendinant darnaus vystymo reikalavimus būtina, kad auganti ekonomika spartintų socialinę pažangą ir gerintų aplinkos būklę, kad socialinè politika skatintų 
subalansuotos ir darnios ekonomikos augimą, o aplinkos politika būtų ekonomiškai efektyvi. Vienas svarbiausių šios strategijos tikslų - siekis, kad augant ekonomikai gamtos išteklių naudojimas ir aplinkos tarša augtų daug lèčiau nei ekonomika arba visai nustotų augusi (EC Sustainable development, 2014).

Lietuvos darnaus vystymosi strategija, patvirtinta Lietuvos Respublikos Vyriausybès 2003 m. rugsèjo 11 d. nutarimu Nr. 1160. 2006 m. birželio 9 d. priimta darnaus vystymosi strategija buvo atnaujinta Lietuvos Respublikos Vyriausybès $2009 \mathrm{~m}$. rugsèjo 16 d. nutarimu Nr. 1247. Joje numatoma užtikrinti tinkamą aplinkosaugą - neviršyti ES leistinų taršos normatyvų, laikytis tarptautinių konvencijų reikalavimų, ribojančių aplinkos taršą. Norint iggyvendinti šiuos uždavinius pagrindinį dėmesị reikia skirti mokslinei pažangai, žinioms ir inovacinių aplinkosaugos priemonių igyvendinimui, kurių pagrindu galima būtų ịdiegti naujausias, mažesnį neigiamą poveikị aplinkai darančias technologijas.

Straipsnis skirtas rodiklių analizei, kurie leistų tinkamiau ịvertinti vandens taršos problemas Baltijos jūros regione. Moksliniai šios srities tyrimai skirti ịvertinti darnaus vystymo reikalavimų vykdymo galimybes nutekamųjų vandenų sektoriaus veikloje, akcentuojant informacinès bazès sukūrimo uždavinius ir pasiūlant priemones jų informacinio aprūpinimo infrastruktūrai plètoti (Dzemydiené et al., 2008; Dzemydiené ir Maskeliūnas, 2011). Duomenys pateikiami, taikant duomenų saugyklų (DS) analizés priemones Europos aplinkos informacijos ir stebejjimo tinklo (EIONET) duomenų bazèje (Document by..., 2006; Saarenmaa, 2002). Darbai, susiję su šios informacijos infrastruktūros išvystymu ReportNet srityje vandens išteklių valdymo sektoriuje (Document by the European Network of Environmental Authorities (ENEA), 2006; Dzemydienè ir Maskeliūnas, 2011), pateikti literatūros šaltiniuose.

\section{Sprendimai, numatantys ekonominès veiklos ir aplinkos apsaugos reikalavimus}

Norint pasiekti gerų rezultatų darnaus vystymosi srityje svarbu užtikrinti tarptautinių, valstybinių, regioninių ir vietinių interesų suderinamumą bei pagrindinių darnaus vystymosi nuostatu igyvendinimą, sudaryti galimybes visuomenei aktyviai dalyvauti darnaus vystymosi procesuose. Svarbu užtikrinti teisės aktais (Lietuvos Respublikos aplinkos ministerija..., 2014; Lietuvos Respublikos Vyriausybès 2009-09-16 nutarimas Nr. 1247 ir 2011-03-30 nutarimas Nr. 379) numatytą valstybės darnaus vystymosi politikos formavimą ir vykdymą. Pagrindinès darnaus vystymosi nuostatos turètų būti įteisintos šios srities teisés aktuose ir integruotos ị regionų ir savivaldybių veiklos planavimo dokumentus.

Aplinkos kokybės rodikliai susiję su oro, vandens ir atliekų tvarkymo galimybèmis, kurioms daro ịtaką taršos objektuose veikiančių valymo įrenginių efektyvumas. Visos su ekonomikos plètra susijusios sritys (transportas, pramonè, energetikos ir žemès ūkis) veikia aplinką.

Analizuojant aplinkos kokybės sprendimus dèmesio skiriama šioms sritims - oro ir vandens taršos mažinimui, klimato kaitos priemonių igyvendinimui turint tikslą 
sumažinti $\mathrm{CO}_{2}$ išmetamų teršalų kiekius, kraštovaizdžio ir biologinès ịvairovès išsaugojimui. Norint užtikrinti aplinkos kokybę, svarbu tinkamas atliekų tvarkymas. Ekonomikos plètra analizuojama pagrindinių ūkio šakų - transporto, pramonès, energetikos, žemès ūkio, būsto ir turizmo - poveikio aplinkai požiūriu; socialinis vystymasis užimtumo, skurdo ir socialinès atskirties aspektais. Socialinei plètrai priklauso visuomenès sveikatos, švietimo ir mokslo, kultūrinio savitumo ir tapatumo išsaugojimo bei darnaus vartojimo problemos.

Aplinkosaugos srityje valstybė turi kontroliuoti poveikị aplinkai ir raginti ūkio subjektus bei valstybės institucijas vykdyti neigiamo poveikio aplinkai ir žmonių sveikatai prevenciją. Svarbu efektyviai naudoti ES paramą bei valstybės lěšas vandens tiekimo ir vandens nuotekų infrastruktūrai modernizuoti bei vandens išteklių valdymo sistemai ir šiuolaikiškai atliekų tvarkymo sistemai sukurti.

Jūros ir vandenynai sudaro 71 proc. žemès paviršiaus, o sausuma 29 proc. Tačiau, JAV atliktos Geologinès apžvalgos duomenimis, visą Žemės paviršiuje esantị vandenị būtų galima sutalpinti ị 1,4 tūkst. km skersmens rutuli (Žemės skersmuo - 12760 $\mathrm{km}$ ) (USGS Science..., 2013). Klimato ir gèlo vandens sistemos yra sujungtos ị visumą. Tačiau šioje sistemoje gyventojų veikla - ekonomika, technologijos, vandens išteklių valdymas daro didžiulę tiesioginę ịtaką saugiam vandens išteklių naudojimui tiek kiekybès, tiek kokybès prasme (Kundzewicz et al., 2007). Vandens išteklių paklausa priklauso nuo gyventoju gyvenimo būdo, svarbus veiksnys, darantis įtaką vandens suvartojimui, yra maistas ir jo gamyba (1 pav.).

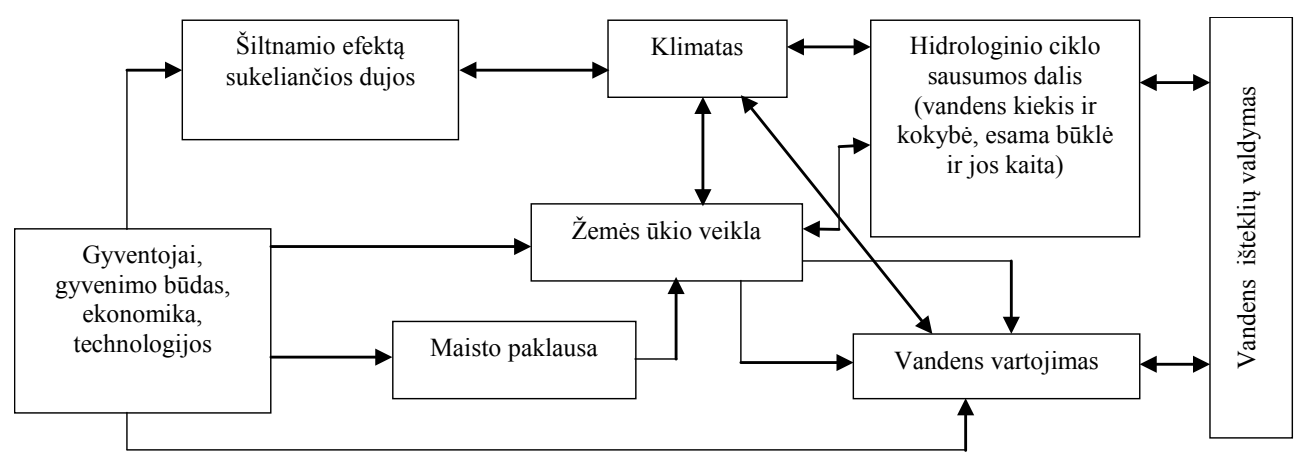

Šaltinis: sudaryta pagal (Kundzewicz et al., 2007)

1 pav. Pagrindiniai ekonomikos ir gyventojų daromos veiklos faktoriai, darantys ịtaką gèlo vandens ištekliams ir jų valdymui

Visų Baltijos jūros regione išsidèsčiusių valstybių, kaip ir Lietuvos, tikslas - pasiekti, kad požeminio vandens, upių, ežerų, Kuršių marių ir Baltijos jūros vandens ekosistemos išlaikytų didelę ịvairovę. Svarbu pasiekti, kad paviršiniai vandens telkiniai tiktų poilsio reikmėms, o visi šalies gyventojai gautų saugos ir kokybės reikalavimus atitinkantị geriamąji vandenị.

Pagal pirmojo prioriteto uždavinius numatyta paskatinti gamtos išteklių, visų pirma vandens resursų bei kraštovaizdžio ir biologinès įvairovés, išsaugojimą, sudarant sąlygas efektyviam jų pritaikymui gyventojų ir ūkio reikmėms, skelbiami rezultatai 
kad bus pagerëjusi vandens telkinių būklè (vandens telkinių, kurių būklè pagerès, dalis nuo bendro telkinių skaičiaus, 40 proc.) (Lietuvos Respublikos apsaugos ministerija, 2014). Trečio prioriteto uždaviniai, susiję su aplinka ir darniu vystymusi, siejami su vandens tiekimo ir nuotekų tvarkymo sistemų renovavimu ir plètra. Tai sudaro gyventojų, gaunančių geros kokybès geriamąji vandenị iš centralizuotų vandens tiekimo sistemų, skaičiaus padidejjimas (proc. nuo esamo skaičiaus) ir su nuotekų i aplinką patenkančios taršos sumažėimas (proc. nuo esamo kiekio). Lietuvos Respublikos aplinkos ministerijos ataskaitose skelbiami rezultatai, kad per 2004-2013 m. laikotarpi 80 proc. renovuotos ir išplèstos viešojo vandens tiekimo ir nuotekų tvarkymo sistemos bei pastatyta 20 proc. aglomeracijų paviršinių nuotekų valymo įrenginių, priklausomai nuo poreikio.

Šiam tikslui igyvendinti svarbu laiku išspręsti šiuos uždavinius:

- siekti sumažinti sutelktąją taršą azotu 810 tonų, fosforu - 85 tonomis, biocheminị deguonies suvartojimą per 7 paras - 1050 tonų, palyginti su 2004 metais;

- sumažinti pasklidąją taršą azotu ir fosforu;

- ìdiegti upių baseinų principu pagrịstą vandens išteklių valdymo sistemą - sudaryti galimybes visiems šalies gyventojams aktyviai dalyvauti siūlant priemones ir igyvendinant vandens telkinių vandens saugos tikslus;

- užtikrinti, kad visa ūkinè veikla būtų organizuota taip, kad nesudarytų sąlygų i paviršinius ir požeminius vandens telkinius patekti pavojingoms aplinkai ir žmonių sveikatai medžiagoms (Lietuvos Respublikos Vyriausybės 2009-09-16 nutarimas Nr. 1247).

Norint igyvendinti šiuos uždavinius svarbu mažinti paviršinio ir požeminio vandens taršą, tinkamai naudoti tam tikslui skiriamas valstybès, savivaldybių, privačias ir ES struktūrinių fondų paramos lěšas.

\section{Nuotekų išleidimo ì paviršinius vandenis apskaitos infrastruktūra ir rodiklių vertinimas}

Paviršinio vandens taršą sudaro ūkio, buities ir gamybos nuotekų išleidimo ị paviršinius vandenis procesai. Ieškant tinkamų taršos apskaitos metodų ir jų ịvertinimo galimybių, darant sprendimus, reiktų atkreipti dėmeș̣ $\mathfrak{i}$ vandens taršos rodiklius, jų tinkamą pasirinkimą ir ịvertinimo priemones.

Vykdant vandens išteklių ir nuotekų gamtosaugos reikalavimus, kuriama vandens išteklių valdymo informacinè sistema (WRMIS), kurioje kaupiami duomenys apie kiekvienos ES šalies vandens išteklių ir nuotekų apskaitą (DANCEE..., 2003; Dzemydienè ir Maskeliūnas, 2011; Saanremaa, 2002). Sistemoje WRMIS sukurta tiesioginès kreipties prieiga, kuri leidžia pateikti operatyvius vandens monitoringo (stebėsenos), kontrolinių patikrinimų, ūkio subjektų statistinių atsiskaitomybių duomenis. 


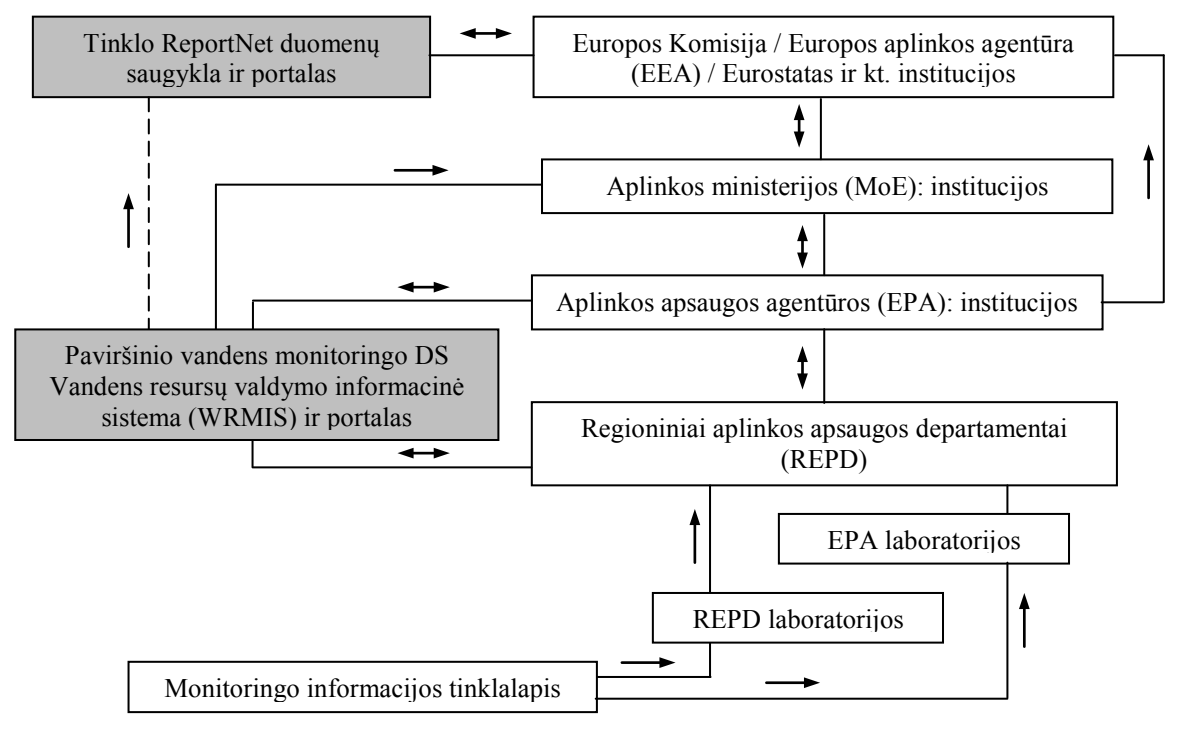

2 pav. Duomenų saugyklų ir duomenų srautų infrastruktūra ReportNet tinkle ir sąsajos su vandens resursų valdymo sistema WRMIS

Užtikrinant tinkamą didelių duomenų saugyklų darbą ir repozitorijų konceptualią infrastruktūrą išgaunama duomenų saugyklų informacija įvairiais analitiniais pjūviais, pasitelkiant OLAP ir MOLAP technologijas, siejant informacijos perteikimą su geografinèmis informacinèmis sistemomis. Tai pagrindinè informacinè duomenu saugykla, leidžianti išgauti duomenis apie paviršinio vandens kokybės situaciją upių ir ežerų vandens akvatorijose, požeminio vandens išteklius ir jų būklę, taškinių nuotekų šaltinius, išleidžiančius nuotekas ị visų rūšių vandens telkinius, ir pan.

Duomenų srautų struktūra ir sąsajos su vandens resursų valdymo sistema (WRMIS) pateikta 2 pav. - atvaizduoti duomenų srautai tarp ReportNet infrastruktūrai pavaldžių komponenčiu ir ES institucijų, atsakingų už aplinkosaugos klausimus.

Europos aplinkos informacijos ir stebejjimo tinklas (EIONET) yra atsakingas už ReportNet tinklo sąveikos palaikymą, duomenų perdavimą sprendimų priemimo institucijoms, taip užtikrinant integruotą ir darnią paramą ir tinkamą duomenų ir informacijos srautų infrastruktūrą.

Jungtinis tyrimų centras (JTC) kaupia visus paviršinio vandens informacijos duomenų saugyklų duomenis, gaunamus iš visų ES šalių. Visos šalys teikia duomenis apie konkrečius geologinių, hidrologinių ir meteorologinių duomenų pasikeitimus. Tarnybos, atsakingos už informacijos operatyvų perteikimą, Lietuvoje yra: LGT - Lietuvos geologijos tarnyba; LHMS - Lietuvos hidrometeorologine tarnyba; LRAM - Lietuvos Respublikos aplinkos ministerija; MRC - Jūrinių tyrimų centras ir kitos įmonès, ịstaigos ir organizacijos. 
1 lentele. Pagrindiniai užteršto vandens nuotekų vertinimo rodikliai ir statistiniai duomenys pagal Lietuvos Respublikos statistikos departamento teikiamus duomenis Eurostato sistemai

(2000-2010 m. laikotarpiu)

\begin{tabular}{|c|c|c|c|c|c|c|c|}
\hline $\begin{array}{l}\text { Užteršto vandens nuotekų } \\
\text { vertinimo rodikliai }\end{array}$ & $2000 \mathrm{~m}$. & $2005 \mathrm{~m}$ & $2006 \mathrm{~m}$ & $2007 \mathrm{~m}$. & $2008 \mathrm{~m}$. & $2009 \mathrm{~m}$. & $2010 \mathrm{~m}$. \\
\hline Bendras nuotekų kiekis mln. $\mathrm{m}^{3}$ & 171,6 & 174,3 & 166,4 & 188,5 & 175,7 & 170,0 & 182,0 \\
\hline Tūkst. $\mathrm{m}^{3} /$ mln. Lt BVP & 3,7 & 2,4 & 2,0 & 1,9 & 1,6 & 1,8 & 1,9 \\
\hline $\begin{array}{l}\text { I atvirus vandens telkinius } \\
\text { patenkančių teršalų kiekis, } t \text {. }\end{array}$ & $2000 \mathrm{~m}$. & $2005 \mathrm{~m}$. & $2006 \mathrm{~m}$. & $2007 \mathrm{~m}$. & $2008 \mathrm{~m}$. & $2009 \mathrm{~m}$. & $2010 \mathrm{~m}$. \\
\hline Organinės medžiagos $\mathrm{BDS}_{7}$ & 6085,1 & 3818,3 & 3421,7 & 3685,8 & 2394,4 & 1785,1 & 1838,9 \\
\hline Skendinčios medžiagos & 7109,4 & 4607,0 & 4344,9 & 5911,6 & 3871,2 & 3323,4 & 3495,1 \\
\hline Bendrasis azotas & 3695,4 & 2837,8 & 2818,2 & 2949,2 & 2368,4 & 1978,8 & 1919,9 \\
\hline Bendrasis fosforas & 653,5 & 355,3 & 336,8 & 315,8 & 241,9 & 186,5 & 167,4 \\
\hline Naftos produktai & 63,7 & 63,2 & 58,8 & 64,9 & 46,1 & 40,5 & 47,3 \\
\hline $\begin{array}{l}\text { Išvalytų iki normatyvų nuotekų } \\
\text { dalis, proc. }\end{array}$ & 13,9 & 67,0 & 67,1 & 69,2 & 72,4 & 88,9 & 90,6 \\
\hline
\end{tabular}

Pagrindiniai rodikliai, vertinant užteršto vandens nuotekas, pateikti 1 lentelëje. Šiuos duomenis pateikia visos su nuotekų apskaita susijusios įmonès ir organizacijos, teikiančios duomenis Lietuvos Respublikos statistikos departamentui, ir šie duomenys siunčiami ị duomenų saugyklas, priklausančias Eurostato statistinei informacinei sistemai.

\section{4. Ūkio, buities ir gamybos nuotekų išleidimo ị paviršinius vandenis taršą įvertinantys duomenys}

Nesukūrus ir nemodernizavus nuotekų valymo įrenginių ir nuotekų surinkimo tinklų, netaikant daugiau priemonių žemės ūkio taršai mažinti, nepavyks iki reikiamo lygio sumažinti taršos. Neskiriant pakankamai lěšų upių baseinų valdymo planų ir priemonių programoms igyvendinti, nepagerés vandens telkinių būklè. Jeigu nebus likviduojamos cheminèmis medžiagomis užterštos teritorijos, gali prastėti ir požeminio vandens būklè.

Ūkio, buities ir gamybos nuotekų išleidimas ị paviršiaus vandenis pagal apskritis netolygus. Pagal Lietuvos Respublikos statistikos departamento duomenis, nuoteku išleidimas ị paviršinius vandenis $2012 \mathrm{~m}$. buvo didžiausias Kauno ir Šiaulių apskrityse ir atitinkamai sudare 2337 299,0 ir 2938 537,7 tūkst. m3 per metus (3 pav.). 


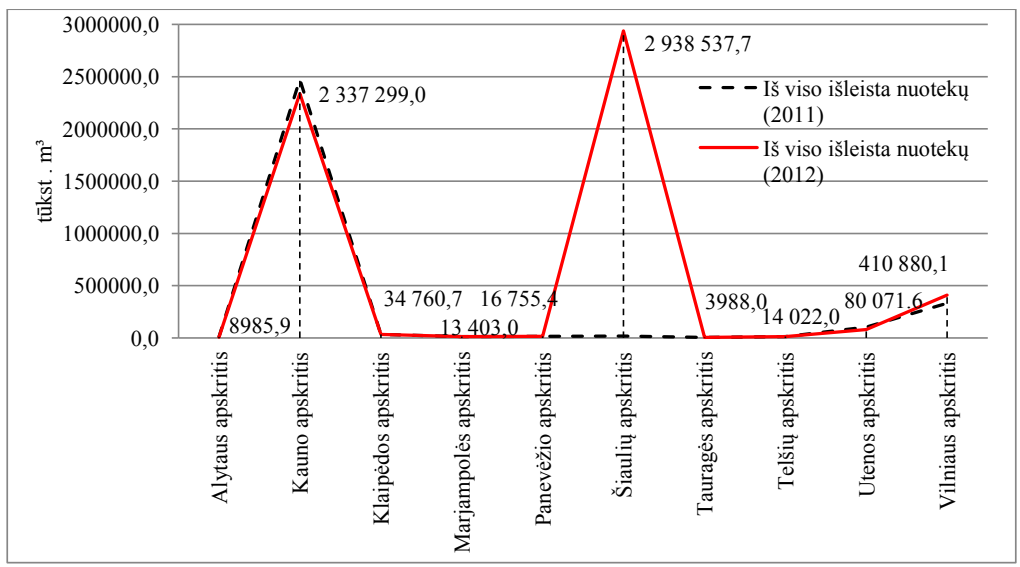

3 pav. Ükio, buities ir gamybos nuotekų išleidimas ị paviršinius vandenis tūkst. $\mathrm{m}^{3}$ pagal apskritis 2011-2012 m.

Dauguma kaimiškųjų gyvenviečių gyventojų būstų neprijungti prie nuotekų tvarkymo infrastruktūros. Nuotekas tvarko įvairaus pajėgumo įmonès, daugelis iš jų nepajegios užtikrinti paslaugų kokybès ir plètros. Nuotekų tvarkymo paslaugu savikaina kaimo gyvenamosiose vietovėse didejja sparčiau negu vartotojų pajamos. Daugelis vandens tiekimo įmonių dirba nuostolingai, nepajėgia investuoti į infrastruktūros tobulinimą ir plètrą. Vandens tiekimo ir nuotekų tvarkymo infrastruktūros neatitinka poreikių, yra neekonomiškos. İmonès neturi pakankamai lèšų prižiūrèti poreikius atitinkančią infrastruktūrą. Didžią̧ą dalị vandens telkinių taršos sukelia žemès ūkio veikla, kurios neigiamą poveikị ženkliai sumažinti kol kas nepavyksta (Lietuvos Respublikos Vyriausybės 2009-09-16 nutarimas Nr. 1247).

Rezultatai, gauti analizuojant oficialius 2011-2012 m. duomenis (Lietuvos Respublikos statistikos departamentas, 2014) ir atsakant ị klausimą - kiek išleista ūkio, buities ir gamybos nuotekų (proc.) ì paviršinius vandenis pagal apskritis, kurių nereikia valyti, lyginant su visomis apskrityje ị paviršiaus vandenis išleistomis nuotekomis, iliustruoja, kad didžiausias tokių nuotekų procentas per 2012 m. rastas Kauno, Šiaulių, Utenos ir Vilniaus apskrityse (4 pav.).

Pramoninès ir komercinès veiklos atliekų šalinimas teršiant dirvožemị yra pastebimas ir tampa svarbiausiu giluminių bei paviršinių vandenų užterštumo šaltiniu. Vandens taršos procesai susiję su oro ir dirvožemio taršos procesais per bendrą vandens cirkuliacinị ciklą. Tyrimai rodo, jei dabartinès dirvožemio teršimo tendencijos visoje ES tęsis, $2025 \mathrm{~m}$. sričių skaičius, kurias reikès valyti, išaugs 50 proc. Kita vertus, šalyse, kurių duomenys apie tokias priemones yra prieinami, per pastaruosius 30 metu buvo išvalyta daugiau nei 80000 vietų.

Kaip rodo statistiniai duomenys, dalis nuotekų buvo išvalyta iki normos (4 pav.). 


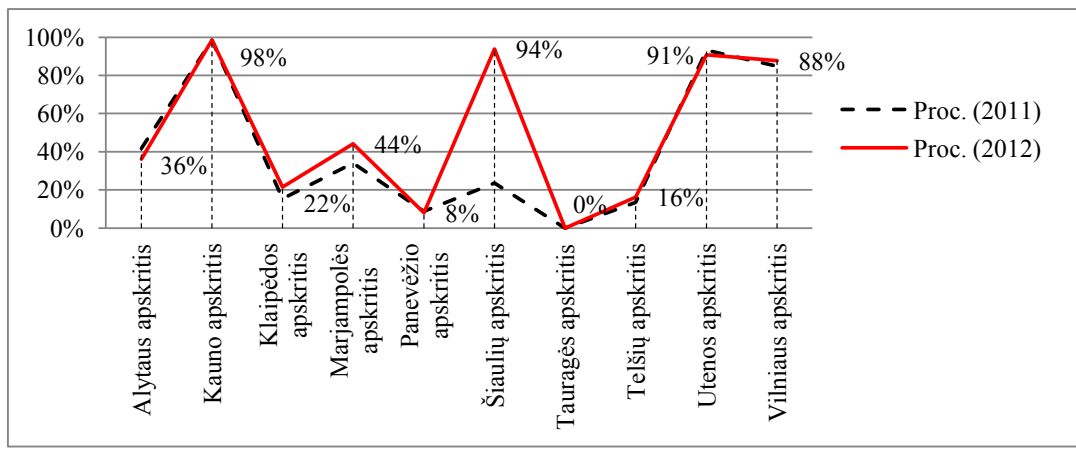

4 pav. Išleista ūkio, buities ir gamybos nuotekų (proc.) it paviršinius vandenis, kurių nereikia valyti, 2011-2012 m. pagal apskritis

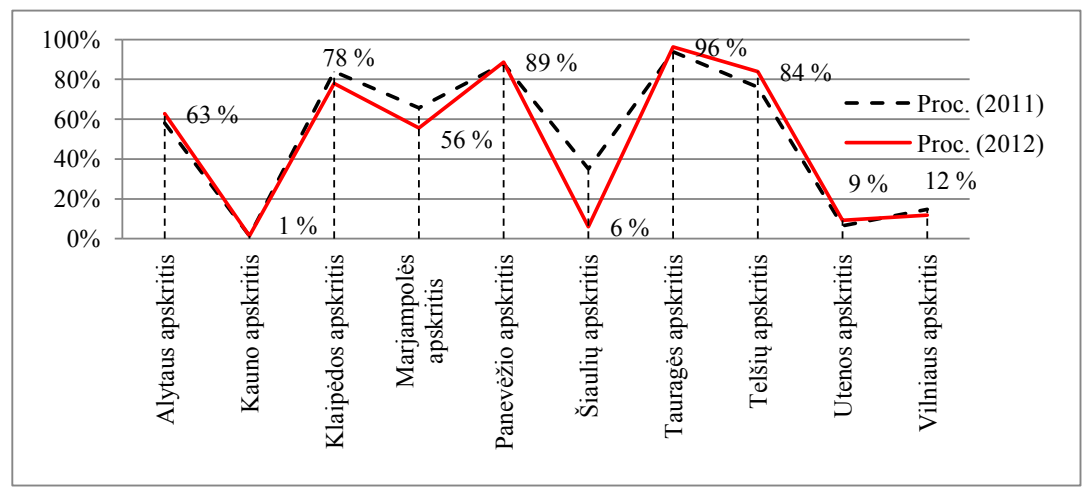

5 pav. Išleista ūkio, buities ir gamybos nuotekų (proc.) i paviršinius vandenis, išvalytų iki normos, pagal apskritis 2011-2012 m.

Rezultatai, kurie iliustruoja neišvalytų nuotekų išleidimo procesus pagal Lietuvos apskritis ị nutekamuosius vandenis (6 pav.).

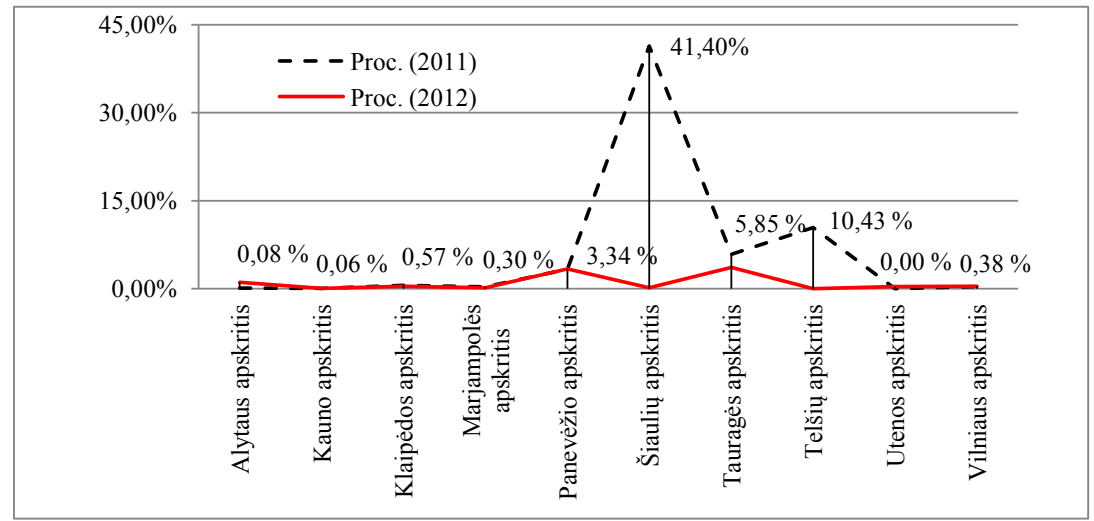

6 pav. Duomenys apie nuotekų kiekius (proc.) i paviršinius vandenis bei nepakankamai išvalytų nuotekų kiekius pagal apskritis, 2011-2012 m.

(Lietuvos Respublikos statistikos departamentas, 2014) 


\section{Lietuvos Baltijos jūros regiono aplinkosaugos rodikliams daromos įtakos analizè}

Pagrindinis Baltijos jūros šalių tikslas - pasiekti gerą Baltijos jūros aplinkos būklę. 2013 m. spalio 3 d. Baltijos jūros šalys Lietuva, Latvija, Estija, Lenkija, Vokietija, Suomija, Švedija, Rusija, Danija patvirtino deklaraciją, nusakančią pagrindines Baltijos jūros aplinkos apsaugos problemas ir tikslus transporto, žemės ūkio, žuvininkystės, pavojingų medžiagų koncentracijų mažinimo, biologinès ịvairovés, saugios laivybos, tarpvalstybinių pernašų finansavimo srityse.

Metinès nacionalinės išlaidos užterštų teritorijų valdymui sudaro vidutiniškai apie 12 eurų vienam gyventojui, su maždaug svyruojančiais skaičiais nuo 0,2 iki daugiau kaip 20 eurų vienam gyventojui per ataskaitinị laikotarpi ES šalyse. Tai vidutiniškai atitinka 0,7 proc. nacionalinio BVP vidurkio, pagal metinių nacionalinių išlaidų kiekius, tenkančius užterštų teritorijų valymui, lyginant su BVP vienetui, pagal ataskaitų duomenis.

Didžiausia dalis išlaidų yra naudojama valymo priemonėms (beveik 60 proc. visų išlaidų) ir tiriamos teritorijos investicijoms (apie 40 proc. visų išlaidų). Reikètų pažymèti, kad tiriamų taškų skaičius yra daug didesnis nei išvalomų vietų skaičius. ES šalyse per 2005-2013 m. laikotarpi pramonės objektų reabilitacija buvo finansuojama struktūrinių fondų lèšomis, naudojant bendrą biudžetą.

Norint sumažinti Baltijos jūros taršą konvencijos šalims buvo pateikti Švedijos mokslininkų skaičiavimais grindžiami Baltijos jūros taršos mažinimo rodikliai. Šie rodikliai leido ịvertinti šalių Baltijos jūros taršą. Pagal pateiktus skaičiavimus Lietuva iki $2021 \mathrm{~m}$. nuotekose turètų sumažinti šiu i ̉ Baltijos jūrą išmetamų cheminių teršalų: nuotekose reikia sumažinti 8970 tonų azoto ir 1470 tonų fosforo (Lietuvos Respublikos aplinkos ministerija, 2013).

Iš Lietuvos teritorijos ị Baltijos jūrą patenkantis teršalų kiekis tonomis nuo 2009-2010 m. pastebimai augo (žr. 7 pav.). Užterštumas organinèmis medžiagomis didejo nuo 68273 tonų iki 76690 tonų; bendruoju azotu - nuo 31310 tonų iki 45021 tonų; bendruoju fosforu - nuo 1298 tonų iki 1815 tonų. Jūros užterštumo svyravimai ženklių teigiamų pokyčių ir didesniame laiko intervale, lyginant su 2005 m., taip pat nepateikia, o užterštumas bendruoju azotu ir fosforu netgi padidèjo (Lietuvos Respublikos statistikos departamentas, 2013).

I apkrovos skaičiavimus ịtrauktas iš Lietuvos teritorijos per Kaliningrado srities teritoriją - Nemuno atšaką Giliją - ị Baltijos jūrą patenkantis teršalų kiekis. Organinių ir biogeninių medžiagų krūvių pokyčius veikia tiek taršos mastas, tiek ir upių debitas. 


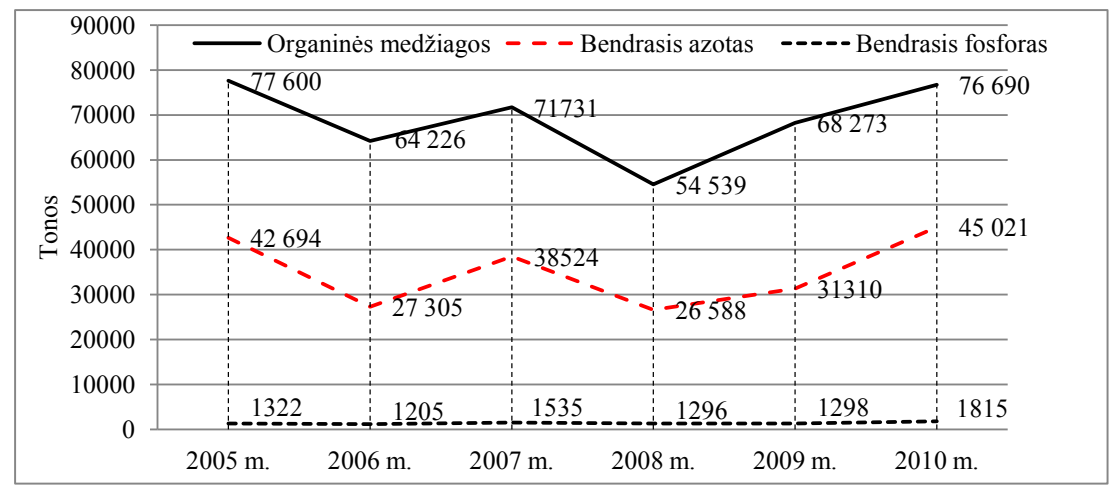

7 pav. Duomenys, atspindintys teršalų prietaką ị Baltijos jūrą (tonomis) 2005-2010 m. (pagal Lietuvos statistikos departamento duomenis, 2013)

\section{Išvados}

Kaip rodo gauti nuotekų apskaitos ir taršos rodiklių analizės rezultatai, ekonominių veiklos subjektų daroma tarša ir ịtaka Baltijos jūros regiono užterštumui nemažèja. Taršos rodiklių dinamika kinta, tačiau pastebimo tolygaus mažejimo statistinių duomenų analizè neatskleidè.

Mažinant taršą svarbiu veiksniu tampa atsakinga ịmonių veikla. İmonių gamybos plètros būdai turi būti grindžiami tiesioginès atsakomybės už aplinkos taršą priemonemis. Nesilaikant aplinkosaugos reikalavimų taikyti pamatuotas ir teisès aktuose reglamentuojamas atsakomybės už taršą priemones. Teisinis reglamentavimas turètų numatyti ir, esant reikalui, griežtinti bei numatyti efektyvesnius apmokestinimo už taršią veiklą būdus. Svarbu paremti ir skatinti aplinkos neteršiančią ịmonių veiklą, taikyti inovacijas, užtikrinančias efektyvius taršos mažinimo būdus.

Daugiau dèmesio reiktų skirti aplinkos apsaugai numatant strategini ir taktini planavimą, operatyvią kontrolę, ekonominès - socialinès - ekologinès pusiausvyros ivvertinimą.

Rekomenduojama stebėti daromos taršos poveikị, nuolat tikrinti valymo sistemų darbą ir vykdyti ekologinès pusiausvyros rodiklių apskaitą.

\section{Literatūra}

den Boer J.; den Boer J.; Jager J. 2007. LCA-

IWM: A decision support tool for sustainability assessment of waste management systems. Waste Management. 27(8): 10321045.

DANCEE 2003 - Danish Co-operation for the Environment in Eastern Europe 2003 project "Transposition of the EU Water Framework Directive and Elaboration of a National Strategy for the Management of Water Resources in Lithuania”.
Document by the European Network of Environmental Authorities (ENEA). 2006. The contribution of structural and cohesion funds to a better environment. Luxembourg: Office for Official Publications of the European Communities.

Dzemydienè, D.; Maskeliūnas, S.; Jacobsen, K. 2008. Sustainable management of water resources based on web services and distributed data warehouses. Technological 
and Economic Development of Economy. 14 (1), 38-50.

Dzemydiene, D.; Maskeliunas, S. 2011. Development of Multi-Componential Decision Support System in Dynamically Changing Application Domain of Environment Protection, Efficient Decision Support Systems - Practice and Challenges From Current to Future. Chiang Jao (Ed.). In Tech, 405-422.

Dzemydiene, D.; Maskeliunas, S.; Dzemyda, I. 2008. Interoperability of information system components for monitoring of sewage and intelligent analysis of water resources. Technological and Economic Development of Economy. 14 (3): 260-278.

European Commission. Sustainable development [interaktyvus]. [žiūrèta 2014-04-04]. <http:// ec.europa.eu/environment/eussd/>.

Kundzewicz, Z. W.; Mata, L. J. 2007. Freshwater resources and their management [interaktyvus]. Cambridge University Press, Cambridge, UK, 173-210 [žiūrèta 2014-0224]. <https://www.ipcc.ch/pdf/assessmentreport/ar4/wg2/ar4-wg2-chapter3.pdf $>$.

Lietuvos Respublikos aplinkos ministerija 2013. Nauji iššūkiai Baltijos jūrai apsaugoti [interaktyvus]. [žiūrèta 2014-04-04]. $<$ http://www.am.lt/VI/article.php3?article_id $=13660>$.
Lietuvos statistikos departamentas 2013. Lietuvos statistikos metraštis 2013.Vilnius.

Lietuvos statistikos departamentas 2014. Oficialiosios statistikos portalas [interaktyvus]. [žiūrèta 2014-04-04]. <http://osp.stat.gov.lt/>.

Lietuvos Respublikos Vyriausybès $2009 \mathrm{~m}$. rugsèjo 16 d. nutarimas Nr. 1247 „Dèl Lietuvos Respublikos Vyriausybès $2003 \mathrm{~m}$. rugsèjo 11 d. nutarimo Nr. 1160 „Dèl Nacionalinès darnaus vystymosi strategijos patvirtinimo ir igyvendinimo" pakeitimo". Valstybès žinios. 2009, Nr. 121-5215.

Lietuvos Respublikos Vyriausybès $2011 \mathrm{~m}$. kovo 30 d. nutarimas Nr. 379 „Dèl Lietuvos Respublikos Vyriausybès 2003 m. rugsèjo 11 d. nutarimo Nr. 1160 „Dèl Nacionalinès darnaus vystymosi strategijos patvirtinimo ir igyvendinimo" pakeitimo". Valstybès ž $i$ nios. 2011, Nr. 41-1949.

USGS Science for changing World. How much water is there on, in, and above the Earth? [interaktyvus]. Water Science School [žiūrèta 2014-03-24]. <http://ga.water.usgs. gov/edu/earthhowmuch.html $>$.

Saarenmaa, H. 2002. ReportNet: Development of common tools and a shared information infrastructure for the European Environmental Information System. NFP/EIONET Group Meeting paper, 2nd edition.

\title{
POSSIBILITIES OF INFORMATION INFRASTRUCTURE IN EVALUATION OF ENVIRONMENTAL POLLUTION AND WATER QUALITY BY IMPLEMENTING THE SOLUTIONS OF SUSTAINABLE DEVELOPMENT
}

\author{
Ramute Naujikienè \\ Mykolas Romeris University, Lithuania, riman@mruni.eu \\ Dalè Dzemydienè \\ Mykolas Romeris University, Lithuania,daledz@mruni.eu
}

\section{Summary}

The purpose - of the article is attached to the examination of information infrastructure for the assessment of water resource planning and water treatment activities, to provide data warehouse (DW) analysis measuring environmental and water pollution and indicators for the evaluation based on the requirements of sustainable development. 
Methodology - the analysis is performed by revealing the factors affecting sustainable development decisions. The insights of scientists are demonstrated by assessing the situation of environmental pollution, the appropriate search parameters, which allow revealing environmental and water contamination by waste water. Secondary data analysis was performed in order to reveal surface water contamination assessment districts in Lithuania and the Baltic Sea region and to summarise the results.

It is very important for business activities to implement methods and tools based on a sense of responsibility for environmental pollution through the use of methods for increasing corporate responsibility, supporting measures to promote stimulation resulting in emission reduction, and efficiency of techniques. The paper presents the results of surface water pollution obtained according to the monitoring data and benchmarking analysis in the districts of Lithuania and the Baltic Sea. It can be concluded that the economic factors of enterprise functioning on the occasion of pollution also impacts the pollution of the Baltic Sea.

More and more attention in the sustainable development of the implementation process should be given to decreasing population and increasing responsibility of economic operators for measures of environmental management levels: strategic and tactical planning, operational control, evaluation of economic, social and ecological balance. The regulatory importance in determining the impact on the environment should also be kept in mind.

The results - were based on the obtained wastewater monitoring and benchmarking results of the analysis of economic operators and the impact of pollution on the contamination of the Baltic Sea. Pollution indicators are changing, but the statistical analysis of the data did not reveal any significant gradual decrease. It is important to control the resulting pollution of the environment, by constantly checking the operation of cleaning systems, and to carry out the ecological balance of the accounting.

Research limitations - the implementation of innovative solutions in the economic development of areas, related factors affecting the sustainable development of the system and the change of their characteristics. The analysis of environmental performance solutions focus on such components as air, water, climate, landscape and biodiversity increase.

The practical significance - of the study reveals sustainable development opportunities for wastewater compliance monitoring and water treatment sector activities; it identifies the existing problems that need to be addressed in order to ensure the quality of water and a clean environment.

Originality/value - the article analyses the problems associated with environmental contamination situations and search for appropriate indicators, which provides an illustration of the water contamination processes in the Baltic Sea region. The results of the study demonstrate the quality of water pollution by means of the indicators provided by information infrastructure based on the implementation of sustainable development decisions.

Research type: a conceptual analysis of the study and data delivery.

Keywords: information systems, data warehouses (DW), sustainable development, water pollution indicators. 